et al. Heart transplantation in patients 65 years of age and older: a comparative analysis of 40 patients. Ann Thorac Surg. 1996;62: 1442-7.

4. Blanche C, Blanche DA, Kearney B, Sandhu M, Czer LS, Kamlot A, et al. Heart transplantation in patients seventy years of age and older: a comparative analysis of outcome. J Thorac Cardiovasc Surg. 2001; 121:532-41.

5. Bull DA, Karwande SV, Hawkins JA, Neumayer LA, Taylor DO, Jones $\mathrm{KW}$, et al. Long-term results of cardiac transplantation in patients over sixty years. J Thorac Cardiovasc Surg. 1996;111:423-8.

6. Borkon AM, Muehlebach GF, Jones PG, Bresnahan DR Jr, Genton $\mathrm{RE}$, Gorton ME, et al. Analysis of the effect of age on survival after heart transplantation. J Heart Lung Transplant. 1999;18:668-74.

7. Hosenpud JD, Bennett LE, Keck BM, Fiol B, Boucek MM, Novick RJ. The registry of the International Society for Heart and Lung Trans- plantation. Sixteenth official report-1999. J Heart Lung Transplant. 1999; 18:611-26

8. Tsai TP, Chaux A, Matloff JM, Kass RM, Gray RJ, DeRobertis MA, et al. Ten-year experience of cardiac surgery in patients aged 80 years and over. Ann Thorac Surg. 1994;58:445-51.

9. John R, Rajasinghe HA, Chen JM, Weinberg AD, Sinha P, Mancini $\mathrm{DM}$, et al. Long-term outcomes after cardiac transplantation: an experience based on different eras of immunosuppressive therapy. Ann Thorac Surg. 2001;72:440-9.

10. Marelli D, Laks H, Kobashigawa JA, Bresson J, Ardehali A, Esmailian F, et al. Seventeen-year experience with 1,083 heart transplants at a single institution. Ann Thorac Surg. 2002;74:1558-67.

11. Robbins RC, Barlow CW, Oyer PE, Hunt SA, Miller JL, Reitz BA, et al. Thirty years of cardiac transplantation at Stanford University. J Thorac Cardiovasc Surg. 1999;117:939-51.

\title{
Superior vena cava stenosis: A delayed BioGlue complication
}

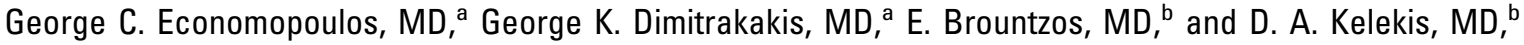 \\ North Faliro and Athens, Greece
}

W e report a case of superior vena cava (SVC) stenosis with upper body venous hypertension after application of biologic glue in the vicinity of the SVC after a double valve replacement and an annuloplasty procedure. The SVC stenosis was managed successfully with balloon dilatation and stent placement.

\section{Clinical Summary}

A 63-year-old man was scheduled for double (aortic and mitral) valve replacement and tricuspid valve annuloplasty. Bicaval cannulation was performed through the right atrial appendage for the SVC and the atriocaval junction for the inferior vena cava; standard ascending aortic cannulation was also performed. Antegrade and retrograde cold blood cardioplegia with moderate core hypothermia $\left(30^{\circ} \mathrm{C}\right)$ constituted the cardioprotective strategy. The exposure of mitral and tricuspid valves was obtained through a superior transseptal approach; exposure of the aortic valve was obtained through a transverse aortotomy. After the mitral and the aortic valve replacements, a DeVega tricuspid valve annuloplasty, and closure of the atriotomy incision, there was persistent bleeding from the dome of the left atrium. Despite adequate suturing, local

From the Department of Cardiac Surgery, Metropolitan Hospital, North Faliro, Greece, ${ }^{\mathrm{a}}$ and the Department of Radiology, University of Athens Medical School, Athens, Greece. ${ }^{\mathrm{b}}$

Received for publication Nov 29, 2003; accepted for publication Dec 16, 2003.

Address for reprints: George C. Economopoulos, MD, Director, Cardiac Surgery, Metropolitan Hospital, 9 E Makariou and 1 E Venizelou Sts, Neo Faliro 18547, Greece (E-mail: geconomo@ otenet.gr).

J Thorac Cardiovasc Surg 2004;127:1819-21

$0022-5223 / \$ 30.00$

Copyright $\odot 2004$ by The American Association for Thoracic Surgery

doi:10.1016/j.jtcvs.2003.12.041 sponge packing, reversal of all anticoagulants, and plasma and platelet transfusions, the oozing persisted. A fair amount of BioGlue (Cryolife, Inc, Kennesaw, Ga) was placed on the area, with a successful result. The patient had an uneventful recovery, and he was discharged on the ninth postoperative day.

The patient returned 8 months later, reporting headaches, dizziness especially on bending, and significant swelling of the face and neck. Echocardiography revealed a competent tricuspid valve repair and two well-functioning artificial valves, with satisfactory myocardial performance. A retroaortic and paracaval echodense mass was noted to be compressing the SVC at its junction with the right atrium (Figure 1). An upper-body venogram revealed a severe stenosis $(>90 \%)$ of the SVC (Figure 2, A). Dilatation of the SVC with 7-mm and 12-mm balloons, followed by placement of a $12 \times 64-\mathrm{mm}$ Wallstent (Boston Scientific, Watertown, Mass), successfully relieved the stenosis (Figure 2, B). The patient is doing well without recurrent stenosis 16 months after the procedure.

\section{Discussion}

After the adverse effects of cyanoacrylate-based glue on the aortic tissues became apparent, ${ }^{1-3}$ a new bovine albumin-based glue cross-linked with glutaraldehyde, BioGlue, was introduced into the cardiac surgical market as the new, nontoxic glue for hemostasis. The product is a preparation of bovine albumin cross-linked with glutaraldehyde to form a strong adhesive bond. It is supplied in a two-barrel applicator; the two compartments contain albumin and glutaraldehyde, which are mixed at the time of application. After mixture, the glue solidifies in about 30 seconds and achieves maximum strength in about 2 to 3 minutes. ${ }^{4}$ The use of BioGlue in aortic surgery was met with great initial enthusiasm, because not only did it increase the strength of the friable aortic walls in aortic dissection when it was applied between the dissected aortic layers, it was proved effective as a sealing agent at the anastomotic suture line. ${ }^{5-8}$ 

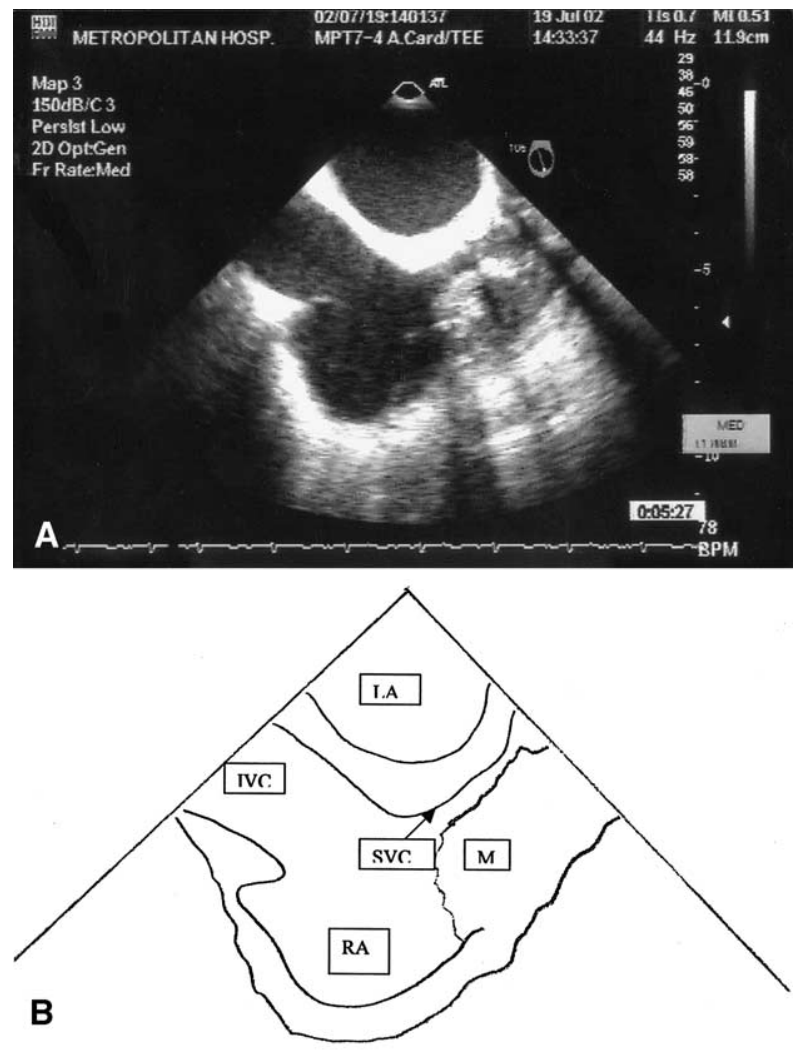

Figure 1. A, Echocardiographic $90^{\circ}$ angle bicaval view demonstrating compression of SVC. B, Diagram representing view. Black arrow points to stenosed SVC. $L A$, Left atrium; IVC, inferior vena cava; $M$, mass; $R A$, right atrium.

Recently, experimental and clinical studies have reported on local tissue damage, local inflammatory response, and risk of pseudoaneurysm formation and great vessel stenosis when BioGlue is applied circumferentially, especially in the pediatric population. ${ }^{9}$ In experiments with piglets, LeMaire and associates ${ }^{10}$ discovered that when BioGlue was applied circumferentially around aortoaortic anastomoses, it impaired vascular growth and caused anastomotic strictures. In our case we believe that an inappropriately large amount of BioGlue was placed between the roof of the left atrium, the adjacent superior cavoatrial junction, and the aortic root. The initially liquid glue, helped by gravity, encircled the cavoatrial junction. After it solidified, it caused the stricture with time.

We believe that BioGlue should be applied sparingly, avoiding spillage, because when the glue is still liquid it may gravitate to dependent, not easily visible areas. Thus it may surround and damage vascular or neuronal tissues, or even compress and constrict low-pressure vascular structures, when it solidifies.

\section{References}

1. Kirsch M, Ginat M, Lecerf L, Houel R, Loisance D. Aortic wall alterations after use of gelatin-resorcinol-formalin glue. Ann Thorac Surg. 2002;73:642-4.
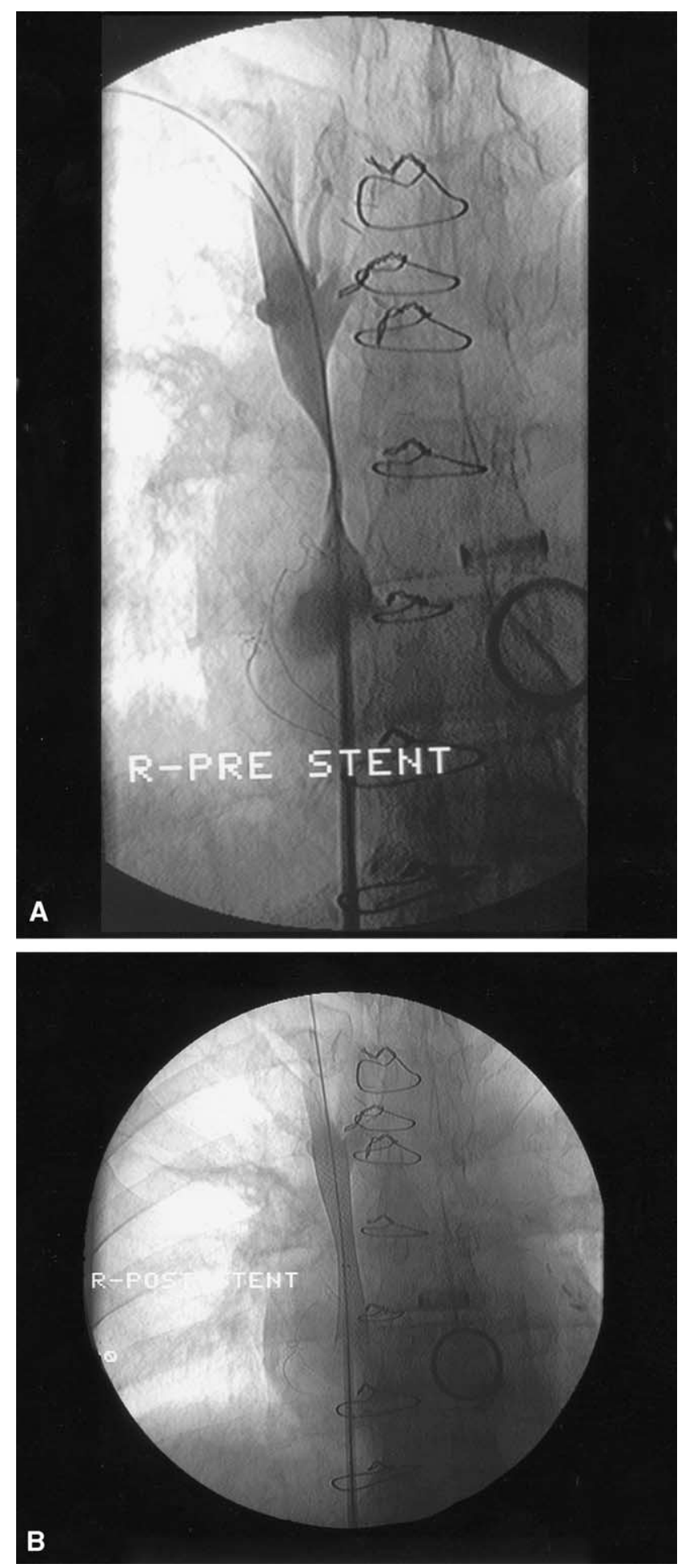

Figure 2. A, Upper-body venogram demonstrating SVC stenosis. B, Poststent SVC.

2. Weissberg D, Goetz RH. Tissue reactions to methyl 2-cyanoacrylate (Eastman 910 monomer). Surg Forum. 1964;15:226-7.

3. Weissberg D. Surgical glue and necrosis of arterial wall. Ann Thorac Surg. 2003;75:1063. 
4. Spotnitz W, Burks S. Use of tissue sealants in cardiac surgery. In: Franco K, Verrier E, editors. Advanced therapy in cardiac surgery. Hamilton, Ontario: BC Decker; 2003. p. 9-10.

5. Coselli JS, Bavaria JE, Fehrenbacher J, Stowe CL, Macheers SK, Gundry SR. Prospective randomized study of a protein-based tissue adhesive used as a hemostatic and structural adjunct in cardiac and vascular anastomotic repair procedures. J Am Coll Surg. 2003;197: 243-52; discussion 252-3.

6. Hewitt CW, Marra SW, Kann BR, Tran HS, Puc MM, Chrzanowski FA, et al. BioGlue surgical adhesive for thoracic aortic repair during coagulopathy: efficacy and histopathology. Ann Thorac Surg. 2000; 71:1609-12.

7. Raanani E, Latter DA, Errett LE, Bonneau DB, Leclerc Y, Salasidis
GC. Use of "BioGlue" in aortic surgical repair. Ann Thorac Surg. 2001;72:638-40

8. Passage J, Jalali H, Tam RK, Harrocks S, O'Brien MF. BioGlue Surgical Adhesive-an appraisal of its indications in cardiac surgery. Ann Thorac Surg. 2002;74:432-7.

9. Kazui T, Washiyama N, Bashar AH, Terada H, Suzuki K, Yamashita $\mathrm{K}$, et al. Role of biologic glue repair of proximal aortic dissection in the development of early and midterm redissection of the aortic root. Ann Thorac Surg. 2001;72:509-14.

10. LeMaire SA, Schmittling ZC, Coselli JS, Undar A, Deady BA, Clubb FJ, et al. BioGlue surgical adhesive impairs aortic growth and causes anastomotic strictures. Ann Thorac Surg. 2002;73: 1500-6.

\title{
New technologies for the treatment of type A aortic dissection: A case report
}

\author{
Stefano Saccani, MD, ${ }^{\mathrm{a}}$ Francesco Nicolini, MD, ${ }^{\mathrm{a}}$ Bruno Borrello, MD, ${ }^{\mathrm{a}}$ Andrea Agostinelli, MD, ${ }^{\text {a }}$ Pietro Larini, MD, \\ Carla Marcato, MD, and Tiziano Gherli, MD, ${ }^{\text {a }}$ Parma, Italy
}

A ortic arch replacement in the treatment of type A aortic dissection is justified in emergency settings to prevent later complications, ${ }^{1}$ even if it is technically demanding and affected by mortality and morbidity. ${ }^{2,3}$ Evolution of residual false lumen remains unpredictable, requiring further high-risk surgical procedures. We report a case of type A aortic dissection treated with ascending aortic replacement associated with a new stent graft positioned in the aortic arch and completed with thoracic endovascular stent graft placement.

\section{Clinical Summary}

A 78-year-old woman was admitted for acute type A aortic dissection. Preoperative transesophageal echocardiography showed a primary tear located above the aortic cusps and extending to the descending thoracic aorta. Cardiopulmonary bypass was established between the right subclavian artery and the right atrium. At mild hypothermia, the ascending aorta was crossclamped, and cold blood cardioplegia was administered through the coronary ostia.

From the Cardiac Surgery Department ${ }^{\mathrm{a}}$ and the Radiology Department, ${ }^{\mathrm{b}}$ University of Parma, Parma, Italy.

Dr Borrello was supported by a research grant from Compagnia di $\mathrm{S}$ Paolo-Torino and MIUR.

Received for publication Nov 24, 2003; revisions requested Dec 31, 2003; accepted for publication Jan 13, 2004.

Address for reprints: Francesco Nicolini, MD, Cattedra e Divisione di Cardiochirurgia, Università degli Studi, Via A. Gramsci 14, 43100 Parma, Italy (E-mail: francesconicolini@libero.it).

J Thorac Cardiovasc Surg 2004;127:1821-3

$0022-5223 / \$ 30.00$

Copyright $\odot 2004$ by The American Association for Thoracic Surgery

doi:10.1016/j.jtcvs.2004.01.020
The proximal aortic stump was reconstructed with continuous mattress sutures and Teflon collars after gelatin-resorcin-formol glue application to the false channel. At a nasopharyngeal temperature of $24^{\circ} \mathrm{C}$, general circulation was arrested, and cerebral protection was obtained by means of right common carotid artery perfusion at a rate of $10 \mathrm{~mL} \cdot \mathrm{kg}^{-1} \cdot \mathrm{min}^{-1}$ through the right subclavian artery. Another tear was found near the origin of the brachiocephalic trunk. The Djumbodis dissection system (Saint Come-Chirurgie, Marseille, France), $9 \mathrm{~cm}$ long, was inserted in the aortic arch and fixed to the aortic wall with 4 transfixed stitches. The device consists of an uncovered stent made of Steel $316 \mathrm{~L}$ provided in 3 lengths $(4,9$, and $14 \mathrm{~cm})$ and mounted on a compliant balloon (Figure 1). The balloon is inflated to adapt the stent to the shape of the aortic arch and to coapt aortic layers. The deployed device presents a large-meshed web and can be superimposed at the origin of the epiaortic vessels without any danger of obstruction. A $30^{\circ} 5-\mathrm{mm}$ endoscope positioned in the aortic arch allowed us to control the correct deployment of the Djumbodis system. The distal end of a Dacron graft was anastomosed to the distal aortic stump and reconstructed with the same technique as used with the proximal one. Extracorporeal circulation was restored, and proximal anastomosis of the Dacron graft was performed during rewarming of the patient. Selective antegrade cerebral perfusion time was 28 minutes, and aortic arch inspection requires 4 minutes of total circulatory arrest. Contrast-enhanced computed tomographic (CT) scanning showed no patent false lumen in the aortic arch. The patient was discharged in an asymptomatic state 12 days after the operation. At 2 months' follow-up CT scanning, a dilation of the false lumen with an aortic isthmian pseudoaneurysm was found: the patient underwent endovascular thoracic stent graft insertion $(2$ segments, $32 \times 32 \times 230$; Talent World Medical Manufacturing Corp, Sunrise, Fla) through the left femoral artery. Stent grafts were proximally positioned with partial overlapping to the distal end of the Djumbodis dissection system 